\title{
MASS PEDAGOGICAL EXPERIENCE OF SENSORY DEVELOPMENT OF PRIMARY SCHOOL STUDENTS
}

\section{МАСОВИЙ ПЕДАГОГІЧНИЙ ДОСВІД СЕНСОРНОГО РОЗВИТКУ УЧНІВ ПОЧАТКОВОЇ ШКОЛИ}

\section{Iryna Barbashova ${ }^{1}$}

DOI: https://doi.org/10.30525/978-9934-26-021-6-4

Abstract. A condition for the effectiveness of sensory development of primary school students is a critical study of the pedagogical experience of its organization. The importance of solving this problem is caused by the fact that school practice lays the foundation of pedagogical science and must take into account both modern scientific achievements and requirements of regulatory state documents. The purpose of the study is to highlight the mass pedagogical experience of sensory development of primary school students. To achieve this goal, written and oral interviews with teachers (questionnaires, interviews, talks) and observation of professional activities were used.

It has been revealed that teachers are aware of the meaning of sensory development and distinguish its leading areas - the forming of vision, hearing and touch of schoolchildren; identify students' typical difficulties in distinguishing mixed colors, complex shapes of objects, sonorous, hissing and whistling consonants, as well as in reproducing the nuances of coloring of objects, the relationship between size and spatial arrangement, inclined and rounded elements of letters, sequence of sounds in an audible word. At the same time, teachers are poorly oriented in the program material of perceptual development, admit insufficient awareness of the laws of sensory processes, and want to know more about the latest techniques and technologies of their forming.

Observation of the real educational process allowed to establish a wide range of didactic influences used by educators in order to form different types of students' perception. Teachers organize studies of colored objects,

\footnotetext{
${ }^{1}$ Doctor in Pedagogy, Associate Professor, Berdyansk State Pedagogical University, Ukraine

(C) Iryna Barbashova
} 
correcting children's verbal designations of colors and their shades; suggest exercises for superimposing objects of different shapes and sizes (arranging by size, placing figures in given proportions, etc.); form students' ideas about speech sounds (observation of the work of speech organs, modeling the properties of sounds with conditional chips, analysis of the phonetic structure of words, etc.); provide perception of musical works, demonstrate sounds of musical instruments and singing voices, use symbols to record the gradations of sounds in pitch, duration and volume, encourage students to reproduce the properties of musical sounds in singing and rhythmic movements; create conditions for touching objects made of different materials. However, teachers do not pay enough attention to distinguishing and naming color nuances, three-dimensional geometric shapes, symbols of voicedness and voicelessness of consonants, comparison of musical sounds by timbre qualities, and verbal characteristics of tactile sensory impressions.

The conducted research proves that the mass pedagogical experience ensures the implementation of program requirements for improving the sensory sphere of primary school students, but shows a lack of teachers' awareness of children's sensory processes and unstable motivation to solve problems of developing students' perception. The prospect for further scientific research is to study the program, educational and methodological resources of forming the processes of perception in primary school students.

\section{1. Ветуп}

Необхідною умовою ефективності сенсорного розвитку молодших школярів [1], є критичне вивчення педагогічного досвіду його організації. Доцільність розв'язання цієї проблеми викликана тим, що безпосередня діяльність учителів, по-перше, закладає базис педагогічної науки, по-друге, має враховувати сучасні наукові здобутки та вимоги нормативних документів, зокрема Концепції реалізації державної політики у сфері реформування загальної середньої освіти «Нова українська школа» [5], Державного стандарту початкової освіти [2], Типових освітніх програм [3; 4].

Мета дослідження полягає у висвітленні масового педагогічного досвіду сенсорного розвитку здобувачів початкової освіти. Поставлену мету конкретизують завдання: охарактеризувати обізнаність учителів щодо формування чуттєвої сфери молодших школярів; оцінити 
результативність освітньої діяльності вчителів з удосконалення в учнів процесів сприймання.

Методами дослідження масового педагогічного досвіду сенсорного розвитку здобувачів початкової освіти обрано письмове й усне опитування (анкетування, інтерв'ю, бесіда) і спостереження професійної діяльності вчителів [6]. Опитуванням було охоплено 148 учителів. Стаж педагогічних працівників - 10 років у середньому, що дає підстави вважати отримані відповіді достовірними. Відвідано 317 уроків із навчальних дисциплін «Українська мова», «Математика», «Я досліджую світ», «Дизайн і технології», «Мистецтво», «Фізична культура» в закладах освіти м. Бердянська.

\section{2. Обізнаність учителів щодо формування чуттєвої сфери молодших школярів}

Питання, за якими здійснювалося анкетне опитування педагогічних працівників і спілкування з ними, об'єднано в блоки й орієнтовано на збір інформації про усвідомлення вчителями наступного: сутності сенсорного розвитку молодших учнів, ступеня сформованості в них чуттєвих процесів, основних напрямків удосконалення перцепції школярів, наявності типових труднощів у сприйманні зовнішніх властивостей предметів і явищ дійсності, сенсорно-розвивального потенціалу змісту початкової освіти, відображеного в освітніх програмах, методичних впливів на чуттєву сферу дітей, загальну організацію навчання школярів перцепції.

Констатуємо, що у визначенні сутності сенсорного розвитку дитячої особистості спостерігається виразна «поліфонія» думок. Цілком точно висловилися із цієї проблеми 43\% учителів, пов'язуючи вдосконалення чуттєвої сфери учнів із формуванням у них процесів сприймання різноманітних зовнішніх властивостей об'єктів, називаючи його провідну мету - створення цілісних уявлень про предмети і явища оточення; пропонуючи специфічні одиниці розвитку перцепції - здібності й уміння, навіть доводячи їхню рефлекторну природу і необхідність організації специфічної діяльності з обстеження дійсності. Сутність сенсорного розвитку в цілому правильно розуміють близько $11 \%$ респондентів, хоча і застосовують це поняття в гранично вузькому значенні, виключно як функціонування тактильних, рідше - зорових 
відчуттів школярів. Маємо визнати, що решта фахівців неправильно усвідомлюють ознаки сенсорного розвитку. Так, 14\% педагогів значно розширюють його межі, ідентифікуючи з формуванням світогляду дитини, набуттям життєвого досвіду, пізнанням навколишнього світу, не пояснюючи, що якісне функціонування перцепції є лише важливою умовою, складником названих процесів; $32 \%$ учителів зовсім не розкрили значення аналізованого поняття.

Щодо питання про необхідність забезпечення чуттєвого розвитку молодших учнів, то всі без винятку респонденти відповіли на нього позитивно, відкинувши тезу про остаточну сформованість сприймання в 6-9-річному віці. Але досягти цієї мети можна, на думку фахівців, по-різному: 70\% із них упевнені в тому, що розвиток сенсорики буде ефективним за умови цілеспрямованого навчання дітей перцепції; інші припускають, що вдосконалення відчуттів може відбуватися опосередковано, під час засвоєння інформації різних дисциплін, формування загальнонавчальних умінь.

До найважливіших сенсорних процесів, які потребують організованого розвитку, 56\% учителів, тобто їхня більшість, відносять удосконалення зору, слуху і дотику школярів. Менша, проте досить велика група фахівців основними вважають дві лінії - зорового і слухового (30\%) або зорового і дотикового (5\%) чуттєвого розвитку; в окремих випадках (по 3\%) опитані асоціюють формування перцепції з якимось одним із зазначених різновидів. Про доцільність розвитку в дітей смаку і нюху майже ніхто з респондентів не згадує. Ця тенденція є очікуваною і віддзеркалює традиційний для методики початкового навчання підхід: більшою мірою сприяти вдосконаленню зорового і слухового сприймання учнів; меншою - дотикового; найменшою - смакового та нюхового, переводячи формування цих перцептивних процесів у площину сімейного виховання.

Труднощі, характерні для дитячого сприймання, педагоги, переважно, пов'язують із недосконалістю функціонування зорового та слухового аналізаторів і вважають типовими помилки школярів щодо розрізнення деяких кольорів і колірних відтінків, складної форми (зокрема їі дрібних деталей), окремих груп приголосних мовленнєвих звуків - сонорних, шиплячих, свистячих, - а також у відтворенні тонких нюансів розфарбування об' єктів зображення, співвідношень між 
ними за розміром і розміщенням у просторі, похилих і заокруглених унизу чи вгорі елементів букв, послідовності звуків у почутому слові. Позитивної оцінки заслуговує намагання пояснити ускладнення перцептивної діяльності учнів обмеженістю їхнього сенсорного досвіду, несформованістю навичок спостереження зовнішніх якостей різних модальностей. Практики також зазначають, що диференціювання властивостей реальних предметів викликає в дітей менші труднощі порівняно з відчуванням ознак певних явищ дійсності, чим і обгрунтовують, наприклад, більш високу точність сприймання кольору, форми, поверхні, температури безпосередньо обстежуваних об'єктів, ніж висоти звуків музики або твердості/м'якості, дзвінкості/глухості мовленнєвих звуків. Разом із тим, виявлено близько 6\% учителів, які наголошують на відсутності в молодших школярів будь-яких помилок у чуттєвому відображенні оточення. Але зіставлення висловлювань 3 отриманими раніше доводить, що саме ці фахівці не змогли визначити сутність сенсорного розвитку дитини, $є$ прихильниками стихійного формування перцептивних процесів. На нашу думку, така позиція відбиває, скоріше, слабке орієнтування в проблемі, що розглядається, ніж засвідчує впевненість в адекватному функціонуванні перцептивних процесів учнів.

Якщо здійснити ранжування відповідей за показником частоти згадувань навчальних дисциплін, зміст яких має виразний сенсорно-розвивальний потенціал, стає очевидною певна закономірність: найпотужнішими в зазначеному контексті курсами педагоги визнають «Я досліджую світ», «Дизайн і технології» й «Мистецтво»; середній ступінь потужності надано математиці, українській мові та музичному мистецтву; до найменш ефективних віднесено фізичну культуру і читання. Слід відмітити, що група респондентів, які розгорнуто висловилися з цього питання, є відносно великою і складає 57\% усіх опитуваних. Із точки зору вчителів, об'єднаних у другу групу (7\%), вдосконаленню чуттєвої сфери школярів сприяє зміст усіх без винятку навчальних предметів. У цілому такі думки можна вважати слушними, але вони не висвітлюють градацію ресурсних можливостей окремих дисциплін. Учасники третьої групи (36\%) на питання не відповіли, що логічно пов'язано з попередньою невизначеністю ними сутності сенсорного розвитку молодших учнів. 
Усвідомлення практиками програмних завдань, спрямованих на забезпечення розвитку перцепції дітей, є досить поверховим. Тільки 38\% фахівців виявили обізнаність зі змістом освітніх програм, зафіксувавши це в досить узагальнених, несистематизованих висловлюваннях стосовно формування окремих сенсорних процесів: організація обстеження предметів і явищ дійсності під час сприймання творів образотворчого й музичного мистецтва, проведення екскурсій, виконання практичних і дослідних дій з обробки різноманітних матеріалів; ознайомлення з геометричними фігурами, теплими і холодними кольорами; групування об'єктів за певними властивостями (формою, розміром, кольором); спостереження за роботою органів артикуляції та вправляння в правильній вимові звуків; відпрацювання графічних навичок відтворення форми букв. Як бачимо, поза увагою вчителів залишилося багато програмних вимог щодо засвоєння різних груп кольорів, способів отримання їхніх відтінків; ознайомлення з площинними і об'ємними геометричними формами, усвідомлення відмінностей об'єктів сприймання за величиною і відношень за розміщенням у просторі; опанування культури письма в зошиті та на дошці; вдосконалення способів обстеження звуків - немовних і мовних, шумових і музичних; розпізнавання на дотик просторових ї фізико-механічних властивостей предметів. При цьому в програмному матеріалі перцептивного спрямування взагалі не орієнтуються 62\% педагогів (отже, не лише ті, у кого виявлено системні труднощі в розумінні головних ознак чуттєвого розвитку дітей, а навіть і ті, хто має про це цілком достовірні уявлення). За нашим переконанням, отримані результати $\epsilon$ свідченням традиційного «розчинення» завдань щодо формування сенсорики у вимогах програм різних дисциплін до рівня загальноосвітньої підготовки школярів.

Тією ж самою причиною можна пояснити найнижчу результативність у визначенні педагогами провідних шляхів удосконалення дитячого сприймання. Лише $12 \%$ респондентів чітко виокремили два напрямки формування в учнів перцепції - розширення кола сенсорних еталонів і вдосконалення способів їхнього застосування в обстеженні предметів і явищ дійсності. Як виявилося під час інтерв'ювання, питома вага цих фахівців мають ще професійну підготовку за спеціальністю «Дошкільна освіта», що, імовірно, і зумовлює поінформо- 
ваність у змістових лініях розвитку сенсорики дітей, адже досліджувана проблема є традиційною для дошкільної психології та педагогіки. Немає підстав стверджувати, що інші учасники анкетування зовсім не розуміють, за якими напрямками потрібно вдосконалювати процеси сприймання учнів початкової школи. Так, багато практиків, хоча й не оперують поняттями «сенсорні еталони» та «способи обстеження», опосередковано виокремлюють загальні шляхи чуттєвого розвитку, висловлюючи цілком адекватні думки щодо його мети і структурних одиниць (нагадаємо, що 43\% учителів раніше наголошували на необхідності формування в молодших школярів образів предметів і явищ, організації цілеспрямованого їх обстеження; відтак, першу позицію можемо асоціювати із сенсорними еталонами, другу - зі способами їхнього застосування в обстеженні оточення). Проте, навіть за умови такого припущення, майже половина педагогів (45\%) із провідними напрямками вдосконалення чуттєвої сфери дітей не визначилася.

Досить показовим, на нашу думку, є підтвердження фахівцями потреби в методичній допомозі щодо організації сенсорного розвитку учнів. Приблизно 65\% респондентів уважають свою теоретичну обізнаність із механізмами функціонування чуттєвих процесів недостатньою, хотіли б ознайомитися 3 передовим педагогічним досвідом, новітніми методиками та технологіями їхнього формування, а серед авторів, рекомендації яких оцінено слушними, зазвичай називають К. Ушинського (5\%), М. Монтессорі (19\%), В. Сухомлинського (14\%), Б. Нікітіна (5\%), О. Савченко (11\%), зовсім не згадуючи про наробки багатьох учених-методистів - М. Богдановича, М. Вашуленка, I. Кирея, Г. Лишенка, О. Лобової, Л. Масол, О. Прищепи, С. Потапової, О. Ростовського, С. Скворцової та ін. Але, незважаючи на слабке орієнтування в науково-методичній літературі з досліджуваної проблеми, майже всі вчителі пропонують застосовувати широке коло впливів сенсорно-розвивального спрямування. Ефективними в навчанні молодших школярів перцепції педагоги справедливо вважають групу наочних методів, особливо спеціально організоване спостереження, тобто обстеження предметів, переконливо доводять необхідність його поєднання зі словесними - поясненням, супроводжувальними бесідами, розповіддю. Не меншого значення фахівці надають практичним методам, перш за все вправам і завданням ігрового характеру (розріз- 
нення кольору, форми об'єктів, їхня класифікація і порівняння за вказаною ознакою; упізнавання предметів на дотик - «Чарівний мішечок»; диференціювання звуків мовлення, звуковий аналіз і синтез - «Упіймай заданий звук», «Який звук зайвий?»; відтворення властивостей «Намалюй теж саме», «Склади візерунок за зразком»), практичним роботам з обробки різноманітних матеріалів (паперу, глини, пластиліну, тіста, ниток, дроту), дослідним роботам. До засобів навчання, якими доцільно користуватись у формуванні сприймання учнів, респонденти відносять ілюстрації, муляжі, звукові схеми, аудіо- і відеозаписи.

Стосовно організації перцептивного розвитку педагогі висловились одностайно: уводити в освітній процес початкової школи нову дисципліну потреби немає, вирішенню відповідних завдань достатньо присвятити окремі уроки з математики, мистецтва (образотворчого й музичного), навчання грамоти, дизайну і технологій, фізичної культури (або елементи цих уроків). Не відкидають учителі й можливості проводити в позаурочний час індивідуальні заняття, підкреслюють важливість екскурсій у збагаченні сенсорного досвіду учнів 1-4 класів.

Здійснене опитування дозволило отримати інформацію, яка віддзеркалює типові думки, оцінки й уподобання фахівців щодо шляхів удосконалення чуттєвої сфери дітей. Однак, за своєю сутністю ці відомості є суб'єктивними, інколи навіть викривленими. Тому додатковим джерелом пізнання педагогічно досвіду виступає спостереження реального освітнього процесу, об'єктивна інтерпретація фактів безпосередньої професійної діяльності.

\section{3. Результативність освітньої діяльності вчителів}

\section{з удосконалення в учнів процесів сприймання}

Виявити методичні особливості розвитку колірних зорових сенсорних процесів дозволило відвідування уроків мистецтва (образотворчого). Ознайомлення школярів із розмаїттям колірних відтінків реалізують усі вчителі, організовуючи обстеження широкого кола носіїв цієї ознаки: шкільного приладдя, одягу, спеціально дібраних ілюстрацій, фарб, олівців, репродукцій художніх творів, дитячих робіт тощо. Спостереження за об'єктами зазвичай супроводжується уточненням, корекцією і збагаченням відповідних словесних позначень. Але, якщо 
оперування назвами спектральних кольорів здійснюється майже на кожному уроці та в багатьох видах зображувальної діяльності, то кількість ситуацій, які б спонукали учнів позначати колірні нюанси, $\epsilon$ значно меншою, що викликає в школярів закономірні утруднення в адекватній характеристиці забарвлення предметів і явищ дійсності.

Засвоєння дітьми нормативної систематизації кольорів забезпечується, на нашу думку, нерівномірно. Як цілком достатні можна оцінити педагогічні впливи, спрямовані на усвідомлення навчального матеріалу про основні та похідні кольори: потрібна інформація повідомляється частіше за все в цікавій або казковій формі; демонструються способи отримання похідних тонів, організовується практична робота зі змішування основних; у закріпленні знань досить часто застосовуються своєрідні «математичні» завдання, коли основні кольори $є$ доданками, суму яких (тобто відповідний похідний тон) необхідно знайти; навчальний матеріал, спочатку опанований першокласниками, актуалізується як опорний на уроках у 2-4 класах, у вступних бесідах, що передують виконанню різних завдань образотворчого мистецтва.

Ефективною вважаємо і роботу стосовно пояснення поділу кольорів на групи теплих і холодних. Виправданими $є$ спроби фахівців установити в дитячій свідомості асоціації цих тонів із теплом сонця, вогню чи, навпаки, із прохолодою повітря, води та льоду. Однак виявилося, що самі вчителі мають деякі труднощі в класифікації кольорів на зазначеному підгрунті. Йдеться про жовто-зелені та червоно-фіолетові кольорі, які з однаковою періодичністю відносять або до теплих, або до холодних тонів, чітко не визначаючи міру виявлення їхніх компонентів. I хоча поділ на теплі та холодні є умовним і кожний колір у поєднанні з іншими може здаватися теплішим або холоднішим, неточність класифікації відтінків педагогами, а відтак і учнями, є небажаною і потребує обов'язкової корекції.

Слід визнати, що ознайомленню молодших школярів 3 ахроматичними і хроматичними, спорідненими і контрастними тонами, їхнім упорядкуванням у спектральну послідовність приділяється значно менше уваги. Звичайно, уроки на ці теми проводяться відповідно до програмних вимог, але активного оперування такими відомостями протягом усього терміну початкового навчання ані з боку вчителів, ані 3 боку школярів ми не спостерігали; наочний посібник «Колірний круг», 
який відбиває характеризовані групування тонів, застосовується епізодично. Імовірним наслідком цього може бути неповне усвідомлення дітьми міжелементних відношень у системі колірних еталонів, обмеження в реалізації виражальних можливостей кольорів.

Відзначимо ще й такий факт: об'єктами спостереження і відтворення частіше за все стають незмішані (основні, первинні) кольори червоний, жовтий, синій - і змішані кольори другого порядку (похідні, вторинні) - оранжевий, зелений, фіолетовий. Кольори більш складної структури, наприклад третього порядку - червоно- та жовто-оранжевий, червоно- та синьо-фіолетовий, жовто- та синьо-зелений - цілеспрямованому сприйманню підлягають рідше і майже не копіюються. Однак, у навколишньої дійсності змішані за тоном відтінки є не менш поширеними, ніж монохромні, а їхнє споглядання вимагає перцептивних процесів найвищого - аналітичного - рівня.

Позитивним у характеризованому контексті можна оцінити досвід учителя-методиста Р. Кіпершлаг (З3СО № 2, м. Бердянськ). Одне із завдань уроку на тему «Осінні враження» (2 клас) полягало у формуванні вмінь утворювати кольори через змішування фарб. Для досягнення цієї мети було організовано розгляд ілюстративного матеріалу підручника, репродукцій картин Л. Афремова «Настрій осені», I. Грабаря «Горобинка», І. Остроухова «Золота осінь»; слухання віршів К. Перелісної «Золота осінь», 3. Федоровської «Осінь». Шляхом постановки ряду питань учителька спонукала учнів до аналізу колірної гами зображень (Який колорит у картин? Які кольори на них переважають? Які фарби полюбляє зміщувати Осінь? Чому їі називають золотою, багряною?; Як ви гадаєте, фарби яких кольорів потрібно використати, щоб отримати такий відтінок? А такий?), а під час лексичної роботи над поетичними текстами - до виділення з мовленнєвого потоку слівназв колірних відтінків, уточнення їхнього номінативного або переносного значення, добору синонімів (розбору підлягали такі вислови: листочки буро-золотаві, руда ліщина, пожовтілі клени, у пурпурі осіннім, діброви в золотому цвіті). Виконувана далі тренувальна вправа включала операції обстеження принесеного дітьми осіннього листя, визначення компонентів їхнього забарвлення, змішування на палітрі необхідних фарб, прикладання листочка-зразка до знайденого відтінка та його корегування в разі потреби. Суміщення об'єктів є, за нашим 
переконанням, дуже важливою дією, адже на рівні предметного маніпулювання забезпечує адекватне порівняння кольорів, а застосований методичний прийом свідчить про усвідомлення педагогом психологічних закономірностей формування перцептивних процесів школярів. На жаль, цей досвід майже одиничний, але він заслуговує на ухвалу і може бути рекомендованим до впровадження в практику початкового навчання.

Специфіку розвитку просторового зорового сприймання молодших учнів було з'ясовано під час відвідування уроків математики, письма, мистецтва (образотворчого), дизайну і технологій, фізичної культури. Виявлено, що фахівці переважно намагаються сформувати в дітей еталони форми, застосовуючи для цього певний алгоритм: демонстрування способу отримання тієї чи іншої геометричної фігури (точка - результат торкання крейдою до дошки або олівцем до паперу; пряма - лінія, відбита натягнутим шпагатом, попередньо натертим крейдою; ламана - зігнутий у кількох місцях дріт; кути різної величини - збільшення чи зменшення відстані між променями розсувної моделі; многокутник - фігура, побудована натягом гумки на цвяхи, набиті на дошку тощо); закріплення первинних образів (діти знаходять об'єкти виучуваної форми в навколишньому середовищі, на ілюстративних зображеннях, виділяють із множини інших фігур); відтворення заданої форми шляхом обведення, копіювання, малювання, креслення, моделювання різноманітних фігур.

Приділяють учителі увагу і навчанню школярів розрізняти предмети за розміром, визначати їхні просторові взаємини. Основними видами завдань, спрямованих на ознайомлення із цими ознаками, $є$ накладання об'єктів сприймання, їхнє вимірювання, упорядковування за зростанням або спаданням величини, розміщення в заданих просторових відношеннях (геометричні диктанти, відбиття співвідношень елементів у зображеннях, розташування вирізаних деталей аплікацій), називання параметрів величини і положення пред'явлених предметів у просторі, повороти на місці та пересування у визначеному напрямку.

Опишемо досвід учителя-методиста Л. Чертищевої (З3СО № 5, м. Бердянськ) як приклад ефективного формування в другокласників форми прямого кута. Педагог, демонструючи процес складання цієї фігури з паперу, паралельно керувала практичними діями дітей: 
«Зігніть великий аркуш навпіл упоперек, тепер зігніть його навпіл уздовж - ви отримали прямий кут». Зробивши такі ж самі моделі 3 аркушів іншої форми і розміру, школярі накладали їх одна на одну, суміщали макети, виготовлені різними учнями, доходили висновку, що всі ці кути рівні; досліджували косинець, за допомогою паперових моделей визначали в ньому прямий кут, училися послуговуватися ним, прикладаючи до обстежуваних кутів і враховуючи таку інформативну ознаку, як збіг сторін і вершин. На наступних етапах уроку учням пропонувалося знайти прямі кути в шкільному обладнанні (такими «знахідками» частіше за все були краї стільниці, шкільної дошки, учнівського зошита, підручника); зіграти в гру «Уважне око» - ідентифікувати прямі кути на предметних малюнках; вибрати їх за допомогою косинця серед зображених кутів різної величини; накреслити фігуру, орієнтуючись на розліновку аркуша.

Варто зазначити, що цей досвід не є цілком оригінальним, адже його компоненти є досить поширеними в практиці початкового навчання. Проте завдяки чіткої сенсорно-розвивальної спрямованості він набуває певної довершеності: формування уявлення про прямий кут здійснюється від спостереження його провідних ознак до застосування поняття і слова-назви; в обстеженні фігури взаємодіють зоровий і дотиковий аналізатори (на нашу думку, суттєвим доповненням до мимовільного обмацування моделей було б обведення їхнього контуру вказівним пальцем, але педагог цей прийом не використала); передбачено предметне маніпулювання об'єктами з наступним переходом до суто зорового порівняння, що створює ефективні передумови для послідовної інтеріоризації перцептивних дій. На цій підставі вважаємо характеризовані педагогічні впливи позитивними і такими, які мають буди поширеними.

Оцінюючи методичний ресурс удосконалення зорової просторової перцепції в цілому високо, висловимо деякі міркування стосовно його недоліків. Результати проведених спостережень засвідчують, що фахівці, як правило, залучають дітей до обстеження площинних геометричних фігур, об'ємні ж тіла підлягають сприйманню значно рідше. Більш того, їхні нормативні назви можуть замінюватися предметними, наприклад, замість термінів «циліндр» і «конус» вживаються слова «валик», «джгутик», «ковбаска», «локшина», «крапелька», що 
є характерним супроводом виготовлення виробів у техніці ліплення. Цей факт ми пояснюємо намаганням педагогів урахувати вікові особливості молодших школярів, проте оперування лише предметними позначеннями знижує, на нашу думку, рівень науковості навчання i потребує неодмінного застосування нормативних лексем.

Із певними особливостями відбувається ознайомлення учнів із класифікацією еталонів форми. Питома вага припадає на організацію опанування видових понять, у той час як родові поняття розкриваються не завжди, наприклад у процесі засвоєння школярами інформації про квадрат або прямокутник не актуалізується інформація про те, що ці фігури є чотирикутниками, а разом із три-, п'яти-, шестикутниками вони належать до многокутників; не знаходять широкого використання таблиці про відповідні відношення форм. Безумовно, такий підхід не може забезпечити адекватного відображення в дитячій свідомості багаторівневих зв'язків між окремими групами геометричних фігур і ними самими.

Дослідження досвіду вдосконалення фонематичних слухових чуттєвих процесів молодших учнів здійснено нами за результатами аналізу уроків української мови переважно в 1-2 класах, оскільки саме на цьому етапі початкової освіти вироблення усвідомленості фонетичних явищ займає центральне місце. Відзначимо, що більшість учителів успішно й у повному обсязі вирішують завдання сенсорного спрямування, створюючи ефективні умови для формування в школярів еталонних уявлень про мовні звуки на основі спостережень за роботою мовленнєвих органів, моделювання властивостей звуків умовними символами, аналітико-синтетичного обстеження фонетичної структури слів.

Так, доволі поширеними в професійній діяльності можна відзначити прийоми зіставлення мовних звуків із немовними: дітям доводилося розрізняти на слух вібрацію скляних і металевих предметів, шарудіння паперу, звучання барабана, бубна, ксилофона, дзвіночка, голоси птахів, продемонстровані в аудіозаписі, імітувати різні природні звуки - мукання корови, кування зозулі, гарчання собаки, квоктання курки тощо. Часто, принаймні в період навчання грамоти, педагоги пропонували школярам споглядати, дивлячись у дзеркальце, як працюють органи мовлення (губи, верхні чи нижні зуби, 
різні частини язика - передня, середня або задня), відчути струмінь видихуваного повітря долонею та дрижання голосових зв'язок кінчиками пальців, прикладених до шиї, категоризувати почуті звуки на основі отриманих вражень.

Для позначення якостей мовних звуків усі без винятку фахівці застосовували загальноприйняті фішки, обов'язково пояснюючи явища, які вони символізують: кружечок - відсутність перепони, одна чи дві рисочки - iї наявність і силу. Деякі педагогі використовували ще парні малюнки для фіксування дзвінкості та глухості приголосних звуків - дзвоник і його закреслений варіант, дзвоник і навушники, стилізовані смайлики - один із відкритими «вушками», другий - is «вушками», які закриті долонями. На цьому слід зупинитися окремо. За нашим уявленням, ці сигнали скоріше унаочнюють лексичне значення слів «дзвінкий» і «глухий», ніж розкривають причину аналізованих відмінностей приголосних, адже коливання голосових зв'язок або їхній спокій вони не відбивають, до того ж є певні труднощі в їхньому зображенні на дошці й у зошиті. Проте намагання вчителів якимось чином змоделювати дзвінкість і глухість приголосних звуків заслуговує позитивної оцінки й актуалізує пошуки відповідних знаків.

Щодо навчання учнів аналітико-синтетичних перцептивних операцій, то над їхнім формуванням педагоги працювали майже на всіх уроках навчання грамоти в 1 класі та багатьох уроках у 2 класі. Першокласники вправлялися в упізнаванні виучуваного звука в слові, при чому з різних позицій - на його початку, у середині або в кінці; добирали слова із заданим звуком; поєднували звуки в злиття та, навпаки, виділяли 3 них окремі звуки; послідовно виокремлювали всі звуки слова з опорою на фонетичну схему. Така робота, зазвичай, передує ознайомленню дітей із буквами, відпрацюванню та закріпленню навичок читання. Другокласникам звуковий аналіз вимовленого слова, який полягає у відтворенні всіх звуків, визначенні наголосу і складів, потрібно було доповнити звуко-буквеними зіставленнями і пояснити, у разі потреби, установлену невідповідність. Перелічені дії фахівці визнають базовими для опанування навчального матеріалу про вимову і позначення ненаголошених голосних $\left[\mathrm{e}^{\mathrm{u}}\right],\left[\mathrm{u}^{\mathrm{e}}\right]$, дзвінких і глухих приголосних, подовжених м'яких приголосних, африкатів [дЖิ], [дЗ3], [ДЗ’’]. 
Наведемо для прикладу, як учитель вищої категорії Г. Прасол (ЗЗСО № 20, м. Бердянськ) організовує навчання фонематичного сприймання під час ознайомлення першокласників зі звуками [б], [б’] і буквою Б, б (“бе”). Виокремлення звуків педагог здійснила на матеріалі вірша Н. Забіли:

Будинок білий біля річки

3 балконами на кожен бік

Будує братик і сестричка,

Бо в них і батько будівник.

Після знаходження найуживаніших у вірші звуків [б] і [б’] педагог запропонувала дослідити їхню артикуляцію, спрямовуючи пізнавальний процес школярів низкою запитань: «Які органи задіяні в утворенні цих звуків? Ці звуки є голосними чи приголосними? При вимові якого звуку перешкода на шляху видихуваного повітря є сильнішою? Якою фішкою треба позначити звук [б]?, а звук [б’]?». Унаслідок спостережень діти доходили висновку, що під час вимовляння звуків струмінь повітря проходить через перепону - стиснуті губи, які смикаються ще сильніше при вимові [б’], а відтак, ці звуки є приголосними - твердим і м'яким.

Наступний етап обстеження полягав у порівнянні виучуваних звуків із раніше засвоєними [п] і [П’]. Артикулюючи звуки [б], [б’] без голосу, першокласники встановлювали такий самий спосіб творення, як і звуків [п], [п’], але, якщо в першому випадку голосові зв'язки дрижать, то в другому вони не рухаються (для перевірки функціонування зв’язок учні торкалися їх пальцями). Далі виконувався добір слів, у яких звуки [б], [б’] займали б різну позицію. Найуживанішими були лексеми булка, бабуся, білка, більще, бобер, лебідь, рибка, хліб, краб, зуб, при цьому вчителька нагадала дітям про чітке звучання звука [б] у кінці та середині слова, продемонструвала літературну вимову таких слів. Завершальною вправою було синтетичне поєднання приголосних звуків із голосними (ба, бе, бі, бо, бу та ін.).

Не має сумніву в тому, що реалізовані прийоми мають високу розвивальну ефективність. Підгрунтям для такого висновку є дотримання фахівцем поширених у науково-методичних джерелах рекомендацій щодо формування мовленнєвого слуху молодших школярів; залучення 
до обстеження звуків кількох рецепторів - слухового і дотикового, що сприяє збагаченню й усвідомленню перцептивних образів; аналіз усіх розпізнавальних властивостей, які лежать в основі родових і видових відношень у системі еталонів мовних звуків і дозволяють віднести їх спочатку до групи приголосних, потім - до підгруп твердих або м'яких, дзвінких або глухих (не вживаючи у другому випадку відповідних понять); застосування умовних символів названих якостей, що дає можливість оперувати звуками на предметному рівні з поступовим переходом до виключно слухових зіставлень і сприяє тим самим забезпеченню поетапної інтеріоризації перцептивних дій аналізованої модальності.

Однак, поряд із позитивним досвідом мусимо констатувати і наявність полярних дидактико-методичних впливів на фонематичні відчуття школярів: часто вчителі орієнтують дітей на миттєву категоризацію звуків (голосний чи приголосний?, приголосний твердий чи м'який?) і добір умовних фішок, що їх позначають, нехтуючи організацією систематичних спостережень за артикуляцією одиниць мовлення; серед усіх ознак меншою мірою спрямовують учнів на усвідомлення дзвінкості та глухості звуків, інколи самі припускаються помилок у встановленні відповідних акустичних пар ([дЖ્], [ДЗ3], [ДЗ’'] i [ч], [ц], [ц’]); демонструють неправильну вимову твердих і м’яких приголосних, замінюючи їх сполученнями з голосними (наприклад, замість звуків [д], [д’] застосовують злиття $\partial u, \partial i$ ); не поодинокими $\epsilon$ випадки плутанини педагогів у поняттях «звук» і «буква». На нашу думку, такі недоліки суттєво знижують методичний потенціал формування фонематичного слуху молодших школярів і можуть призвести до спотворення еталонних уявлень про звуки рідної мови, вироблення неадекватних способів їхнього обстеження.

Досвід розвитку музичної слухової сенсорики учнів початкової школи 3'ясовано під час відвідування уроків музичного мистецтва. Серед усіх музично-освітніх завдань, які вирішують фахівці, основну увагу зосередимо на методиці ознайомлення дітей із властивостями звуків музики як своєрідних одиниць ії мови. Учителі, організовуючи сприймання широкого кола творів, закладають основи розрізнення вокальної та інструментальної музики; на достатньому науковому рівні розкривають сутність понять музичних і шумових звуків, для 
чого демонструють звучання багатьох музичних інструментів, співацьких голосів, а також звуків навколишнього світу, окремих ударних інструментів - барабана, бубна, трикутника, тарілок, ложок - i надають дітям можливість їх диференціювати (гра «Упіймай музичні звуки»); створюють ефективні умови для усвідомлення перетворень природних явищ у музичні образи (слухання п’єси Е. Гріга «Пташка», аналіз поетичних текстів про звуки лісу, вокальна імітація співу птахів тощо); повідомляють інформацію про ноти - спеціальні знаки для запису музики.

Цілеспрямованою і вичерпною вважаємо діяльність педагогів із формування в школярів уявлень про гучні й тихі звуки. Показовими в цьому аспекті є аналіз твору Д. Кабалевського «Сурмач і луна»; застосування різних символів для фіксування градацій звуків за характеризованою властивістю (піднімання руки догори в разі гучного звучання, його позначення червоним кружечком, літерою $f$ - форте; у протилежному випадку - опускання руки вниз, використання синього кружечка і букви $p$ - піано; при поступовому посиленні або спаданні сили звучання - знаків «крещендо» $\mathrm{i}$ «димінуендо»); відтворення гучності звуків у вправах, ігрових завданнях, співах. За такою ж схемою і так само ретельно педагоги знайомлять дітей із довгими і короткими звуками шляхом демонстрування музичних уривків із яскравим метро-ритмічним малюнком, наприклад п’єси М. Равеля «Болеро», моделювання чергування звуків різної тривалості за допомогою заповнення клітинок ритмічної стрічки складами $m i-m i, m a$, запис ритму восьмими і четвертними нотами, віддзеркалення пульсу в ритмічних рухах, супровід музичних творів грою на шумових інструментах і задіяння до цього побутових предметів іграшок, баночок із сипучими матеріалами тощо.

Методику формування в учнів, зокрема першокласників, умінь розрізняти звуки за ознакою висоти розкриємо, проаналізувавши досвід старшого вчителя Г. Толкачової (Балківський 33СО, Токмацький район, Запорізька область). Виправданим, на наш погляд, є намагання фахівця надати звуковисотним відношенням предметного характеру. Споглядаючи ілюстративні зображення, школярі асоціювали голоси персонажів - ведмедя, кота і миші - 3 низькими, середніми й високими звуками; порівнювали ці відчуття зі звуками фортепіано різних регістрів, визначали належність своїх голосів до середнього регістру; 
зіставляли рух мелодії розучуваної поспівки і графічної схеми, пересуваючи указку її «сходинками», демонстрували рукою висхідний, горизонтальний (тобто на одній висоті) та низхідний мелодійні напрямки. Закріплення отриманих вражень відбувалося під час слухання п'єси Д. Кабалевського «Зайчик дражнить ведмедика», художні образи якої діти позначали рухами рук (угору, якщо чують високі звуки, та вниз, якщо чують звуки низькі), а також танцювальними елементами (відповідно до звучання підстрибували чи розхитувалися, імітуючи рухи тварин). Такий досвід цілком суголосний з усталеними положеннями музичної педагогіки, заслуговує високої оцінки й поширення, оскільки $\epsilon$ спрямованим на організацію різнопланових слухових спостережень i перехід на цій основі до абстрактних узагальнень, передбачає логічне унаочнення звуковисотних відношень, які вважаються найважливішими, навіть смислорозрізнювальними в музиці.

Продовжуючи характеристику професійної діяльності вчителів із розвитку музичної сенсорики учнів початкової школи, слід відзначити і виявлені недоліки. Так, із чотирьох властивостей музичних звуків висоти, тривалості, гучності, тембру - менш за все підлягають розрізненню тембральні якості, до мінімуму зведено гру на дитячих музичних інструментах. Не знаходять належного застосування навчальні посібники, наприклад «столбиця», матриці з накладними квадратами i прямокутниками тощо, які моделюють звуковисотні і метро-ритмічні відношення звуків; не часто фахівці організовують і сольфеджування за нотним записом, а елементів релятивного методу зі складовими назвами ступенів звукоряду та їхніми ручними позначеннями ми не спостерігали взагалі. І ще одне дуже важливе, на нашу думку, зауваження: саме на уроках музичного мистецтва вчителі інтенсивно користуються педагогічними програмними засобами (ППЗ), у багатьох випадках - тільки ними. На нашу думку, із такою позицією погоджуватися не можна, адже, не зважаючи на всю ефективність електронних підручників, надмірне демонстрування їхніх матеріалів позбавляє дітей можливості чути «живу» інструментальну і вокальну музику.

Способи керування вдосконаленням дотикових відчуттів учнів дозволило дослідити відвідування уроків природознавства і трудового навчання. Установлено, що в практиці початкового навчання кількість завдань, які передбачають безпосереднє тактильне обстеження об'єк- 
тів, не є великою. Зазвичай це ігри за типом «Чарівного мішечку» та вправи із зав'язаними очима, як-от групування предметів за матеріалом, із якого їх виготовлено - глини, дерева, металу, скла, пластмаси, вовни, шовку тощо. Дещо більшою мірою фахівці організовують завдання опосередкованого характеру, коли обмацування об' єктів відбувається паралельно з іншими чуттєвими процесами, зокрема під контролем зору, і включено в різні види художньо-продуктивної діяльності школярів.

Зразком таких сенсорно-розвивальних впливів може бути досвід учителя вищої категорії М. Балабанової (КЗ «Бердянська загальноосвітня санаторна школа-інтернат I-III ступенів» Запорізької обласної ради). На уроці трудового навчання в 2 класі дітям довелося розглянути ілюстрації об'єктів ліплення - чайників кількох видів, визначити їхні загальні складники - основну частину (резервуар для води) i додаткові (носик, ручку, кришку); розділити пластилін на чотири шматочки різного розміру; із найбільшого скачати кулю, приплюснути їі для надання потрібної форми й усталеності; з менших скачати «джгутик» $\mathrm{i}$ «ковбаску» (за термінологією вчителя), виготовити з них ручку та носик і примастити їх до основної частини; скачати ще одну кулю, стекою розрізати іiі навпіл і отримати таким чином кришку, накрити нею чайник. Із нашої точки зору, застосовані педагогом прийоми сприяють формуванню в учнів комплексу еталонних уявлень - про складну форму, величину і розташування іiі елементів, м'якість і пластичність матеріалу; створюють достатні умови для опанування адекватних способів обстеження перелічених ознак, як дотиково-зорових - синхронне обведення контуру поглядом і пальцями в разі розрізнення просторових якостей виробу, - так і суто дотикових, потрібних для відчування фізико-механічних властивостей пластиліну - його розкочування, натискування, витягування, пригладжування тощо. Наведений досвід варто оцінити плідним, хоча він і не позбавлений деяких недоліків: насамперед це пов'язано зі слабкою актуалізацією знань про об'ємні фігури, неточним їхнім називанням. Слід нагадати, що таке саме явище ми спостерігали і в методиці розвитку зорового просторового сприймання, що підтверджує стійкий характер цієї проблеми.

Найпоширенішим у професійній діяльності виявився стихійний спосіб удосконалення дотикової сенсорики школярів. Реалізуючи 
завдання щодо виготовлення різноманітних виробів, ознайомлення 3 багатьма об'єктами живої і неживої природи, фахівці організовують широке коло пізнавальних ситуацій, обов'язковим елементом яких $\epsilon$ тактильне обстеження предметів оточення. Проте увагу дітей на виконанні відповідних розрізнювальних операцій педагогі, зазвичай, не концентрують, як і не пропонують словесно схарактеризувати отримані чуттєві враження.

\section{4. Висновки}

Масовий педагогічний досвід відбиває типовий рівень організації сенсорного розвитку здобувачів початкової освіти. У цілому такий досвід забезпечує реалізацію програмних вимог щодо вдосконалення чуттєвої сфери молодших школярів, проте засвідчує недостатній рівень усвідомлення вчителями особливостей функціонування чуттєвих процесів дитячої особистості, нестійку мотивацію щодо вирішення у власній професійній діяльності завдань із навчання учнів перцепції.

Виявлено, що педагоги усвідомлюють сутність сенсорного розвитку, виокремлюють його провідні напрями - формування зору, слуху й дотику школярів; зазначають типові труднощі учнів у розрізненні змішаних кольорів, складної форми предметів, сонорних, шиплячих і свистячих приголосних мовленнєвих звуків, а також у відтворенні нюансів розфарбування об' єктів зображення, співвідношень між ними за величиною і просторовим розміщенням, похилих і заокруглених елементів букв, послідовності звуків у чутному слові. Разом із тим, учителі слабко орієнтуються в програмному матеріалі перцептивного спрямування, визнають недостатньою обізнаність із закономірностями функціонування чуттєвих процесів, бажають ознайомитися 3 новітніми методиками та технологіями їхнього формування.

Спостереження реального освітнього процесу дозволило встановити широке коло дидактичних впливів, застосованих фахівцями 3 метою формування в учнів різних видів перцепції. Учителі організовують обстеження кольорових об'єктів, корегуючи словесні позначення дітьми кольорів та їхніх відтінків; застосовують вправи з накладання об'єктів різної форми та розміру, упорядковування їх за величиною, розміщення фігур у певних співвідношеннях; формують у школярів уявлення про мовні звуки на основі спостережень за роботою мовлен- 
нєвих органів, моделювання властивостей звуків умовними фішками, аналізу фонетичної структури слів; забезпечують сприймання музичних творів, демонструють звучання музичних інструментів і співацьких голосів, використовують символи для фіксування градацій звуків за висотою, тривалістю й гучністю, спонукають учнів до відтворення властивостей музичних звуків у співах і ритмічних рухах; створюють умови для відчування на дотик предметів, виготовлених із різних матеріалів. Проте, поза увагою вчителів залишаються розрізнення й називання дітьми колірних нюансів, об'ємних геометричних фігур, позначення умовними символами дзвінкості та глухості приголосних звуків, порівняння музичних звуків за тембральними якостями, словесна характеристика дотикових чуттєвих вражень.

Здійснена наукова розвідка не $\epsilon$ вичерпною, іiі перспективою має стати вивчення програмного, навчального й методичного ресурсів формування в школярів процесів сприймання.

\section{Список літератури:}

1. Барбашова I. А. Дидактична система сенсорного розвитку молодших школярів : автореф. дис. д-ра пед. наук : спец. 13.00.09 «Теорія навчання». Київ, 2018. 37 с. URL: http://www.undip.org.ua/upload/Disertation/Rada01/ Автореферат_Барбашової I.A..pdf (дата звернення: 04.12.2020).

2. Про внесення змін до Державного стандарту початкової освіти : Постанова Кабінету Міністрів України від 24.07.2019 № 688. URL: https://zakon.rada.gov.ua/laws/show/688-2019-\%D0\%BF (дата звернення: 04.12.2020).

3. Про затвердження типових освітніх програм для 1-2 класів закладів загальної середньої освіти : Наказ МОН України від 08.10.2019 № 1272. URL: https://mon.gov.ua/ua/npa/pro-zatverdzhennya-tipovih-osvitnih-programdlya-1-2-klasiv-zakladiv-zagalnoyi-serednoyi-osviti (дата звернення: 04.12.2020).

4. Про затвердження типових освітніх програм для 3-4 класів закладів загальної середньої освіти : Наказ МОН України від 08.10.2019 № 1273. URL: https://mon.gov.ua/ua/npa/pro-zatverdzhennya-tipovih-osvitnih-program-dlya-3-4-klasiv-zakladiv-zagalnoyi-serednoyi-osviti-1273 (дата звернення: 04.12.2020).

5. Про схвалення Концепції реалізації державної політики у сфері реформування загальної середньої освіти «Нова українська школа» на період до 2029 року: Розпорядження Кабінету Міністрів України від 22.08.2018 № 988-p. URL: https://zakon.rada.gov.ua/laws/show/988-2016-\%D1\%80 (дата звернення: 04.12.2020).

6. Тверезовська Н. Т., Сидоренко В. К. Методологія педагогічного дослідження. Київ : Центр учбової літератури, 2013. 440 с. 


\section{References:}

1. Barbashova I. A. (2018). Dydaktychna systema sensornogho rozvytku molodshykh shkoljariv [The Didactic System of Junior Schoolchildren's Sensory Development] (Extended abstract of Doctor's thesis). The Institute of Pedagogy of the NAPS of Ukraine. Kyiv. Retrieved from: http://www.undip.org.ua/upload/ Disertation/Rada01/Автореферат_Барбашової I.A..pdf (accessed 04 December 2020). (in Ukrainian)

2. Pro vnesennja zmin do Derzhavnogho standartu pochatkovoji osvity [On amendments to the State standard of primary education]: Postanova Kabinetu Ministriv Ukrainy № 688 (2019, July 24). Retrieved from: https://zakon.rada.gov.ua/ laws/show/688-2019-\%D0\%BF (accessed 04 December 2020). (in Ukrainian)

3. Pro zatverdzhennja typovykh osvitnikh proghram dlja 1-2 klasiv zakladiv zaghaljnoji serednjoji osvity [On approval of model educational programs for 1-2 grades of establishments of general secondary education]: Nakaz MON Ukrainy № 1272 (2019, October 8). Retrieved from: https://mon.gov.ua/ua/npa/ pro-zatverdzhennya-tipovih-osvitnih-program-dlya-1-2-klasiv-zakladiv-zagalnoyi-serednoyi-osviti (accessed 04 December 2020). (in Ukrainian)

4. Pro zatverdzhennja typovykh osvitnikh proghram dlja 3-4 klasiv zakladiv zaghaljnoji serednjoji osvity [On approval of model educational programs for 3-4 classes of establishments of general secondary education]: Nakaz MON Ukrainy № 1273 (2019, October 8). Retrieved from: https://mon.gov.ua/ua/npa/ pro-zatverdzhennya-tipovih-osvitnih-program-dlya-3-4-klasiv-zakladiv-zagalnoyi-serednoyi-osviti-1273 (accessed 04 December 2020). (in Ukrainian)

5. Pro skhvalennja Koncepciji realizaciji derzhavnoji polityky u sferi reformuvannja zaghaljnoji serednjoji osvity «Nova ukrajinsjka shkola» na period do 2029 roku [On approval of the Concept of realization of the state policy in the field of reforming of general secondary education «New Ukrainian school» for the period till 2029]: Rozporjadzhennja Kabinetu Ministriv Ukrainy № 988-r. (2018, August 22). Retrieved from: https://zakon.rada.gov.ua/laws/show/988-2016-\%D1\%80 (accessed 04 December 2020). (in Ukrainian)

6. Tverezovsjka N. T., Sydorenko V. K. (2013). Metodologhija pedaghoghichnogho doslidzhennja [Methodology of pedagogical research]. Kyiv: Centr uchbovoji literatury. (in Ukrainian) 